Ксендзук Валентина Віталіївна

кандидат економічних наук,

Житомирський державний технологічний університет,

Житомир, Україна,

ksiedzuk@ukr.net

\title{
ЛОГІСТИЧНІ ТА ВАЛЮТНІ РИЗИКИ В ДІЯЛЬНОСТІ СУБ'ЄКТІВ ЗОВНІШНЬОЇ ТОРГІВЛІ
}

У статті обгрунтовано вплив логістичних і валютних ризиків на вибір потенційних закордонних контрагентів під час здійснення зовнішньоекономічної діяльності торговельними підприємствами. Для досягнення поставленої мети застосовано загальнонаукові методи дослідження (метод аналізу та синтезу - для дослідження сутності трактування поняття ризиків; метод порівняння та статистичних спостережень - 3 метою виокремлення видів ризиків, які становлять найбільший вплив на етапі вибору та оцінки діяльності потенційних закордонних партнерів, метод порівняння - для характеристики логістичних і валютних ризиків у різних країнах світу на підставі аналізу статистичних даних). У ході дослідження розглянуто сутність поняття «ризики» та обгрунтовано необхідність врахування як негативних, так $\mathrm{i}$ позитивних наслідків впливу ризику на зовнішньоекономічну діяльність торговельних підприємств, на підставі чого сформовано авторське визначення поняття «ризики в зовнішньоекономічній діяльності». Зазначено, що врахування валютних і логістичних ризиків при виборі партнерів у зовнішній торговельній діяльності $є$ важливим етапом пошуку нових зовнішніх контрагентів. Розглянуто основні статистичні показники (зміна валютного курсу української гривні по відношенню до іноземних валют країн світу та Індекс ефективності логістики (Logistics Performance Index)), які характеризують рівень валютних i логістичних ризиків у країнах світу, що є підставою для формування переліку країн - потенційних імпортерів/експортерів для конкретних українських суб'єктів господарювання, що здійснюють операції експорту та імпорту товарів, в частині пошуку та оцінки партнерів у зовнішній торгівлі.

Ключові слова: зовнішня торгівля, експорт, імпорт, валютні ризики, логістичні ризики, зовнішньоекономічна діяльність.

Ksendzuk Valentyna, Candidate of Economics, Zhytomyr State Technological University, Zhytomyr, Ukraine

\section{Logistic and exchange risks in the activities of foreign trade subjects}

The impact of logistics and currency risks on the selection of potential foreign contractors in the implementation of enterprises foreign trade activities has been 
grounded in the article. To achieve this goal, the general scientific methods of research were used (method of analysis and synthesis - to study the essence of the concept of risk interpretation; the method of comparison and statistical observations - in order to distinguish the types of risks that have the greatest impact on the stage of epy potential foreign partners activities selection and evaluation, the method of comparisonto characterize the logistics and currency risks in different countries of the world based on the statistical data analysis). The study examined the essence of the "risk" concept and the necessity of taking into account both negative and positive effects on the trade companies foreign trade activities risk, being the basis for the author's "risks in foreign trade" definition. It is noted that currency and logistic risks when choosing partners in foreign trade activities is an important stage looking for new external counterparties. The main statistical indicators have been considered (the change of the exchange rate of the Ukrainian hryvnia against the foreign currencies of the countries of the world and the Logistics Performance Index), characterizing the level of currency and logistic risks in the countries of the world, being the basis for making a list of potential importers/exporters for specific Ukrainian business entities involved in goods export and import within searching and assessing foreign trade partners.

Key words: foreign trade, export, import, currency risks, logistic risks, foreign economic activity.

Ксендзук Валентина Витальевна, кандидат экономических наук, Житомирский государственный технологический университет, Житомир, Украина

\section{Логистические и валютные риски в деятельности субъектов внешней торговли}

В статье обосновано влияние логистических и валютных рисков на выбор потенциальных зарубежных контрагентов при осуществлении внешнеэкономической деятельности торговыми предприятиями. Для достижения поставленной цели применены общенаучные методы исследования (метод анализа и синтеза - для исследования сущности понятия рисков, метод сравнения и статистических наблюдений - с целью выделения видов рисков, которые составляют наибольшее влияние на этапе выбора и оценки деятельности потенциальных зарубежных партнеров, метод сравнения - для характеристики логистических и валютных рисков в различных странах мира на основании анализа статистических данных). В ходе исследования рассмотрена сущность понятия «риски» и обоснована необходимость учета как отрицательных, так и положительных последствий влияния риска на внешнеэкономическую деятельность торговых предприятий, на основании чего сформировано авторское определение понятия «риски во внешнеэкономической деятельности». Указано, что учет валютных и логистических рисков при выборе партнеров во внешней торговой деятельности является важным 
этапом поиска новых внешних контрагентов. Рассмотрены основные статистические показатели (изменение валютного курса украинской гривны по отношению к иностранным валютам стран мира и Индекс эффективности логистики (Logistics Performance Index)), характеризующих уровень валютных и логистических рисков в странах мира, является основанием для формирования перечня стран потенциальных импортеров/экспортеров для конкретных украинских субъектов хозяйствования, осуществляющих операции экспорта и импорта товаров, в части поиска и оценки партнеров во внешней торговле.

Ключевые слова: внешняя торговля, экспорт, импорт, валютные риски, логистические риски, внешнеэкономическая деятельность.

Вступ. Відкриття зовнішніх ринків для суб'єктів малого та середнього бізнесу сприяє розвитку національної економіки, але разом 3 тим вимагає впровадження нових методик пошуку потенційних закордонних контрагентів. Розширення клієнтської бази підприємства передбачає врахування сукупності чинників, які впливатимуть на процес пошуку і оцінки торговельних партнерів на міжнародному ринку товарів i послуг. Зокрема, важливим аспектом $\epsilon$ врахування ризиків, які виникають у зовнішньоекономічній діяльності на початковому етапі здійснення операцій експорту та імпорту товарів. Ідентифікація ризиків має на меті визначення причини їх виникнення з метою ефективного вибору методів управління ризиками, які повинні забезпечити мінімізацію, попередження виникнення або ж уникнення ризику в зовнішньоекономічній діяльності.

Ризик є одним з основних економічних явищ, яке впливає на діяльність кожного суб'єкта господарювання. Причинами виникнення такого ризику в зовнішньоекономічній діяльності можуть бути: зміна курсу валют, цін при купівлі-продажу товарів на ринку, відсоткових ставок, а також виникнення різних природних явищ, поведінка постачальників i покупців, зміни в законодавчій базі. Крім цього, наявність інформаційної асиметрії продукує непідготовленість суб'єкта господарювання до певних критичних ситуацій за відповідними сферами невизначеності. У зв'язку з цим, виникає необхідність врахування ризиків під час здійснення зовнішньоекономічної діяльності підприємств $з$ метою ефективного використання наявних обмежених ресурсів, нарощення капіталу та досягнення відповідної частки не лише на вітчизняних, а й на міжнародних ринках товарів і послуг, капіталу та праці.

Відповідно до даних статистичних спостережень Державної служби статистики України обсяг експорту товарів та послуг України у 2017 р. становив 52329,6 млн. дол. США, імпорту - 54955,0 млн. дол. Порівняно із 2016 р. експорт збільшився на $16,0 \%$, імпорт - на 23,3\%. Негативне сальдо зовнішньоторговельного балансу становило 2625,4 млн. дол. (у 2016 р. 
позитивне - 541,6 млн. дол.) [1].

Міжнародні потоки капіталу у вигляді інвестиційних вкладень в економіку країни станом в 2016 р. зменшилися на 11,22 \% (з 40725,4 млн. дол. станом на 2015 р. до 36154,5 млн. дол. за 2016 р.), іноземні інвестиції з України в економіку інших країн в 2016 р. (6 315,2 млн. дол.) порівняно 32015 р. (6 456,2 млн. дол.) зменшилися на 0,02 \% [8].

Негативна тенденція розвитку ринку товарів і послуг та фінансового ринку України $є$ одним 3 найважливіших індикаторів економічної та фінансової глобалізації, що супроводжується зростанням ризиків і створює необхідність у впровадженні функцій управління ризиками в діяльність підприємств, в тому числі тих, які здійснюють операції на зовнішніх ринках товарів і послуг.

Формулювання цілей статті. Метою здійснюваного дослідження $\epsilon$ обгрунтування впливу логістичних та валютних ризиків на вибір потенційних закордонних контрагентів під час здійснення зовнішньоекономічної діяльності торговельними підприємствами. Задля вирішення поставленої мети в статті окреслено завдання: розкрити сутність поняття «ризики в зовнішньоекономічній діяльності» та обгрунтувати доцільність врахування валютних та логістичних ризиків при виборі партнерів в зовнішній торгівлі. Крім того, в межах здійснюваного дослідження розглянуто статистичні дані, які характеризують рейтинг країн світу в розрізі впливу валютних та логістичних ризиків, що має практичну цінність для суб' єктів господарювання в частині оцінки діяльності потенційних контрагентів у зовнішній торгівлі.

Методи дослідження. Під час написання статті застосовувалися загальнонаукові методи дослідження, за допомогою яких досягнуто мету та розкрито завдання у сфері ідентифікації та впливу ризиків на здійснення зовнішньоекономічної діяльності підприємства. Зокрема, для дослідження сутності поняття ризиків у діяльності суб'єктів зовнішньої торгівлі застосовувалися методи аналізу та синтезу 3 метою окреслення особливостей ризиків, які виникають у зовнішньоекономічній діяльності. 3 метою виокремлення видів ризиків, які становлять найбільший вплив на етапі вибору та оцінки діяльності потенційних закордонних партнерів, використано метод порівняння та статистичних спостережень. На підставі методу порівняння 3'ясовано, які країни входять до переліку тих, підприємства яких найбільш піддаються впливу аналізованих видів ризиків.

\section{Виклад основного матеріалу дослідження.}

1. Сутність ризиків у зовнішньоекономічній діяльності. У словнику М. Банько (М. Bańko) ризик визначається як:

- «можливість, ймовірність того, що щось не вдасться, що діяльність буде мати неправильний характер (...);

- дія, пов'язана 3 будь-якою небезпекою, яка може мати несприятливі 
наслідки (...)» [11].

Серед дослідників поняття ризику описано двома способами:

- «концепція негативного ризику: ризик розуміється негативно (як загроза) - можливість недосягнення очікуваного ефекту;

- нейтральна концепція ризику: ризик розуміється нейтрально (як можливість);

- можливість отримання результату, який відрізняється від очікуваного» [13].

Польський дослідник Т. Т. Качмарек (Т. Т. Kaczmarek) у своєму дослідженні описує проблеми виникнення ризику в історичному аспекті, посилаючись на найперші спогади про ризики та загрози для здоров'я людей. Автор розкриває основні поняття, що розглядаються разом і часто навіть ідентифікуються, серед яких: невизначеність, незнання, випадковість, ненадійність, сумнівність, загрози. Він також розглядає визначення ризику, що описане в американській літературі, в якому ризик розглядається не лише 3 негативної сторони для діяльності підприємств, але й з врахуванням позитивних ефектів. Т. Т. Качмарек не погоджується з таким підходом, обгрунтовуючи свою критику тим, що «ризик в собі містить неотримання запрограмованих ефектів» [14].

Автор пропонує визначити ризик як «можливість виникнення невдачі та, зокрема, можливість виникнення подій, незалежних від діючого суб'єкта, які він не може точно передбачити і не може повністю запобігти їм, а також які - знижуючи корисні результати та / або збільшуючи витрати - забирають повністю або частково ознаку ефективності, корисності або економічності» [14].

У ході проведеного дослідження наукової літератури у сфері понятійнокатегоріального апарату встановлено, що різні підходи науковців містять лише перелік видів ризиків, які розкривають особливості ведення зовнішньоекономічної діяльності підприємств. Зокрема, група науковців (Л. Маханець [5], М. Левченко [3], А. Свідерська [10]) звертає увагу на те, що необхідно класифікувати ризики в зовнішньоекономічній діяльності на групи залежно від виду діяльності (операційна, фінансова, інвестиційна, і т. д.)

А. П. Рум'янцев та Н. С. Рум'янцева ризики в зовнішньоекономічній діяльності поділяють на «ризики, пов'язані 3 вибором країни, 3 вибором партнера, 3 укладанням міжнародних господарських контрактів, із митним регулюванням, маркетингові, транспортні, комерційні» [9].

Н. Е. Петросян розглядає зовнішньоекономічну діяльність і класифікує «ризики на наступні види: ризики митні, комерційні, маркетингові (інформаційний, галузевий, інноваційний), надійність партнера, політичні, макроекономічні (внутрішня економіка країни, економіка країни-партнера, заборгованість). Також автор виокремлює у структурі ризиків п’ять основних груп: пов'язані з умовами контракту, щодо територіального положення, щодо етапу угоди, щодо можливості впливу на ризик, 
щодо процесу підписання угоди» [7].

Однак, вважаємо, що доцільно охарактеризувати сутність ризиків у сфері ведення зовнішньоекономічної діяльності. Зокрема, варто врахувати представлені тлумачення поняття «ризик» та окреслити ризик у зовнішньоекономічній діяльності 3 врахування його можливих як позитивних, так і негативних наслідків. Адже ризики можуть нести загрози, що мають негативне значення для зовнішньоекономічної діяльності, а також користь, яка позитивно впливатиме на експортно-імпортні операції. Наприклад, падіння валютного курсу національної валюти по відношенню до іноземної позитивно впливатиме на діяльність експортерів, які мають заборгованість від іноземних контрагентів. Натомість, така ж ситуація на валютному ринку негативним чином позначиться на результатах імпортних операцій.

У табл. 1 представлено авторський підхід до розуміння ризиків у зовнішньоекономічній діяльності.

Таблиця 1

\section{Ризики: позитивні та негативні наслідки} для зовнішньоекономічної діяльності підприсмства

\begin{tabular}{|c|c|}
\hline $\begin{array}{l}\text { позитивних наслідків таких змін } \\
\text { (зростання вартості майна або доходів, } \\
\text { зменшення суми зобов'язань або витрат) }\end{array}$ & $\begin{array}{l}\text { негативних наслідків таких змін } \\
\text { (зменшення вартості майна або доходів, } \\
\text { збільшення суми зобов'язань або витрат) }\end{array}$ \\
\hline
\end{tabular}

Запропонований підхід окреслює вплив ризиків на зовнішньоекономічну діяльність підприємств. Таким чином, для суб'єктів господарювання важливо враховувати як позитивні, так і негативні наслідки впливу ризиків на зміни в діяльності. Повертаючись до видів ризиків, які притаманні для суб'єктів зовнішньоекономічної діяльності, варто підкреслити, що валютні та логістичні ризики є одними з основних детермінантів виходу на конкретний зовнішній ринок товарів і послуг. Адже під час вибору країни здійснення зовнішньої торгівлі, суб'єкт господарювання має провести аналіз та оцінку потенційних контрагентів, в тому числі ризиків, пов'язаних з діяльністю в частині співпраці 3 країною походження контрагентів. Тому доцільно розглянути валютні та логістичні ризики, які можуть виникати в українських суб'єктів господарювання під час виходу на зовнішні ринки товарів і послуг.

2. Валютні ризики в зовнішньоекономічній діяльності. Відповідно до МСФ3 7 «Фінансові інструменти: розкриття інформації» [6], «валютний ризик (currency risk) - ризик того, що справедлива вартість або майбутні грошові потоки від фінансового інструмента коливатимуться внаслідок змін валютних 
курсів». Найчастіше у літературі зустрічаються наступні види валютного ризику: ризик, пов' язаний зі змінами обмінного валютного курсу, що впливають на статті балансу; ризик, що виникає при укладанні та виконанні зовнішньоекономічних контрактів; ризик, пов'язаний зі зміною обмінного валютного курсу на макроекономічному рівні та впливає на майбутній фінансово-економічний стан підприємства.

На рис. 1 представлено інтерактивну карту, яка відображає зміну вартості валют країн світу по відношенню до української гривні.

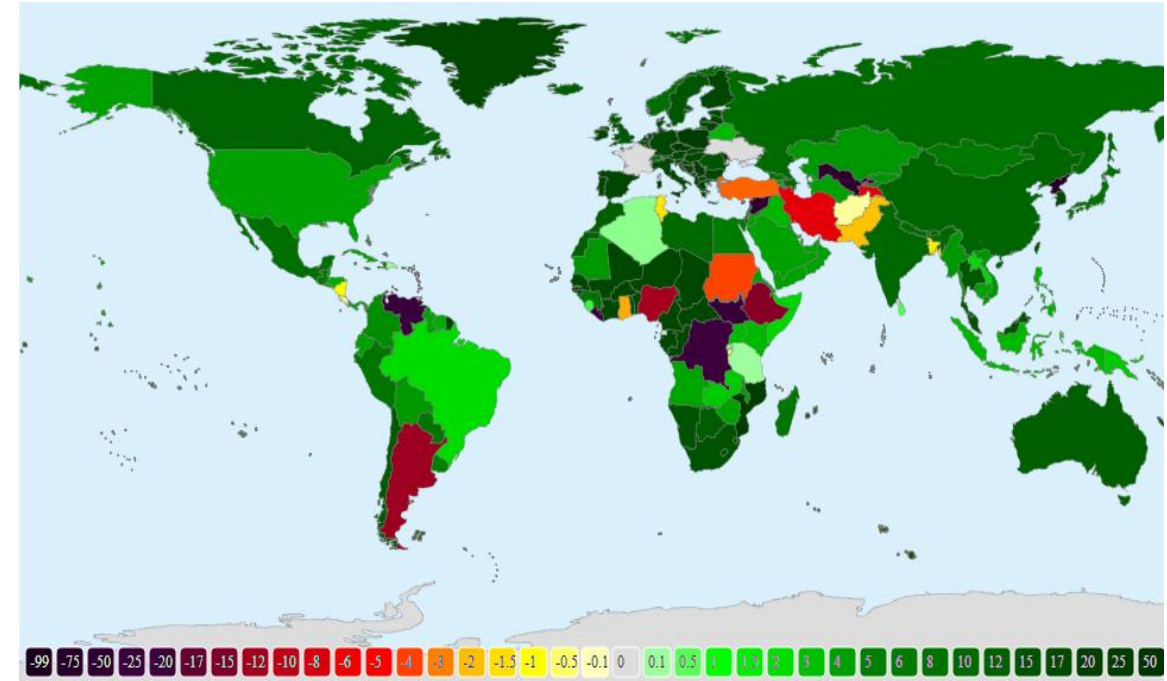

Рис. 1. Зміна вартості валют в краӥнах світу по відношенню до курсу національної валюти - української гривні (01.01.2017-01.01.2018 рр.). Джерело: [12]

Примітка: зелене забарвлення краӥни - підвищення курсу вартості валюти краӥни відносно украӥнської гривні; червоне забарвлення краӥни - знецінення курсу вартості валюти краӥни відносно украӥнської гривні

Валютний ризик є одним із видів ринкового ризику та виникає в результаті діяльності суб'єктів господарювання, що здійснюють операції на зовнішніх ринках в іноземній валюті. Врахування валютних ризиків у зовнішньоекономічній діяльності суб'єктів господарювання дозволяє здійснювати управління ризиками та застосовувати методи, які, в свою чергу, сприяють отриманню стабільного фінансового результату. На вибір потенційних контрагентів впливає економічна ситуація в країні, на ринок якої планується вихід. Адже пошук партнерів для ведення зовнішньоекономічної діяльності має враховувати аспект валюти контракту, яка в подальшому впливає на результат торговельної операції.

Щодо сучасної ситуації на валютному ринку України, як бачимо з рис. 1, національна валюта - українська гривня, знецінюється по відношенню до валют світу - долара США, євро. Для експортерів, 3 однієї сторони, складається 
позитивна ситуація, коли ризик зростання курсу валюти впливає на зростання експортного доходу. Однак, 3 іншої сторони збільшується вартість експортованого товару, що негативним чином позначається на конкурентоздатності українських підприємств на зовнішніх ринках товарів i послуг. Враховуючи той факт, що в Україні останні роки спостерігається негативне сальдо зовнішньоторговельного балансу, імпортери країни втрачають на девальвації валютного курсу української гривні. Таким чином, суб'єкти господарювання перед початком виходу на зовнішні ринки мають здійснити детальний аналіз валютного ризику та оцінку діяльності потенційних контрагентів 3 метою вибору оптимальних та ефективних методів управління валютними ризиками.

3. Логістичні ризики в зовнішньоекономічній діяльності. У науковій літературі «під логістичним ризиком розуміють небезпеку виникнення затримки в роботі ланцюга постачання, зрив постачання або порушення в роботі однієї або декількох ланок ланцюга. До найпоширеніших ризиків належать логістичні ризики, пов'язані із виконанням відповідних логістичних функцій під час виробництва, зберігання, маркування і упакування, консолідації і подрібнення, транспортування різними видами транспорту, документування, розрахунків, розподілення тощо» $[4$, с. 45$]$.

Для оцінки країни 3 погляду їі доступності та легкості здійснення транспортних перевезень використовується Індекс ефективності логістики (Logistics Performance Index). На рис. 2 представлено значення вище згаданого Індексу в країнах світу в 2016 р.

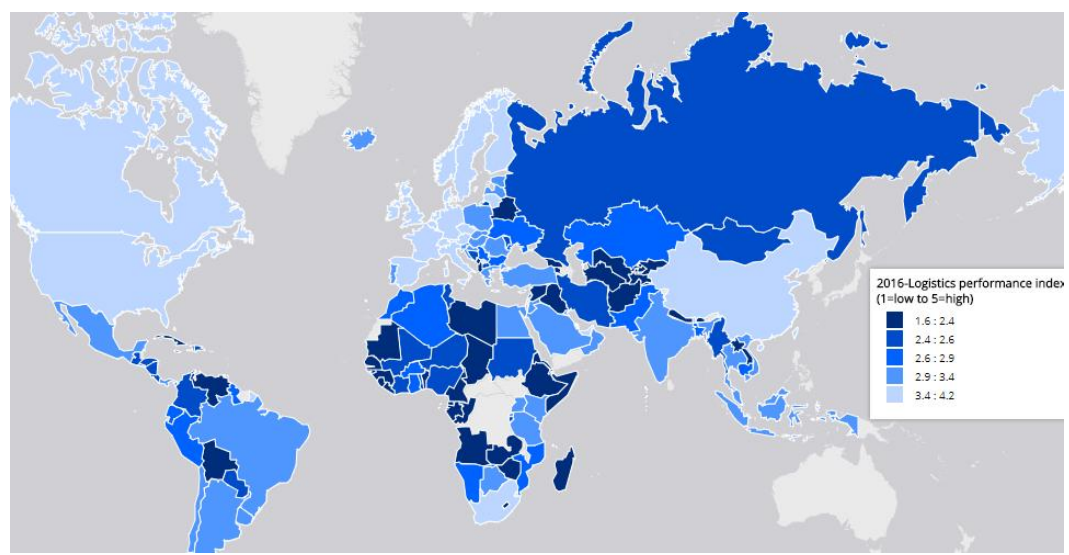

Рис. 2. Індекс ефективності логістики (LPI) в країнах світу в 2016 р. Джерело: [15]

За даним Індексом «країни оцінюються за п’ятибальною системою за декількома окремими характеристиками логістичної сфери, як-от: ефективність митної обробки вантажу, можливості організації міжнародних 
вантажовідправлень, ефективність місцевої логістичної інфраструктури, контроль і відстеження міжнародних вантажовідправлень, витрати на логістику всередині країни, своєчасність доставки вантажів у пункти призначення» [2].

За даними Світового банку перші місця в рейтингу за Індексом ефективності логістики займають: Німеччина, Люксембург, Швеція та Нідерланди. Натомість завершують список такі країни як: Екваторіальна Гвінея, Мавританія, Сомалі, Гаїті та Сирія. Варто зауважити, що Україна в даному рейтингу займає 80 місце і має недостатньо сприятливі умови в частині розвитку логістичної інфраструктури та міжнародних перевезень. Тому при виборі закордонних партнерів аналіз місця країни - потенційних контрагентів, має важливе значення в розрізі врахування та оцінки можливих непередбачуваних ситуацій та ризиків, що виникатимуть у сфері управління логістичних ланцюгами у зовнішній торгівлі.

Висновки 3 даного дослідження і перспективи. Таким чином, у ході дослідження проаналізовано підходи в науковій літературі в частині трактування поняття «ризики» та розглянуто класифікацію ризиків в зовнішньоекономічній діяльності. На підставі цього обгрунтовано доцільність розгляду ризиква як змін, що відбуваються в діяльності підприємства під час виходу та функціонування на зовнішньому ринку товарів i послуг, які призводять до як негативних, так i позитивних наслідків змін вартості майна або доходів, суми зобов'язань або витрат.

На етапі вибору партнерів у зовнішньоекономічній діяльності суб’єкти господарювання оцінюють валютні та логістичні ризики, що є важливим для застосування відповідних методів управління ризиками. Тому в ході дослідження розглянуто основні статистичні показники (зміна валютного курсу гривні по відношенню до іноземних валют та Індекс ефективності логістики), які доцільно аналізувати на етапі пошуку країни потенційних контрагентів. Проведене дослідження характеризує валютні та логістичні ризики з практичної сторони в сфері пошуку та оцінки партнерів у зовнішній торгівлі, на підставі чого дозволяє сформувати перелік країн, які можуть розглядатися як потенційні імпортери/ експортери для конкретних українських суб’єктів господарювання.

\section{Список використаних джерел:}

1. Зовнішньоторговельний баланс України у 2017 році, 14.02.2018 № 61/0/08.2вн-18 [Електронний ресурс] / Державна служба статистики України. Режим доступу: URL: www.ukrstat.gov.ua. - Назва 3 екрану. - Дата звернення 20.02.2018.

2. Індекс ефективності логістики 2016 - Німеччина знову в лідерах [Електронний ресурс] // Экономические известия. - Режим доступу: URL: http://eizvestia.com/uk/ekonomika-ukr/full/366-indeks-efektivnosti-logistiki-2016- 
nimechchina-znovu-v-liderax. - Назва з екрану. - Дата звернення 14.02.2018.

3. Левченко М. О. Формування механізму управління ризиками у зовнішньоекономічній діяльності машинобудівних підприємств : дис. ... канд. екон. наук : 08.00.04 / Левченко М. О. ; Хмельницкий нац.. у-т. - Хмельницький, 2013. 249 c.

4. Мамчин М. М. Вплив логістичних ризиків на підвищення ефективності діяльності підприємств [Електронний ресурс] / М. М. Мамчин, О. А. Русановська. 2011. - - C. 45-51. - Режим доступу: URL: http://ena.lp.edu.ua:8080/bitstream/ntb/13816/1/8_45-51_Vis_720_Menegment.pdf. Назва з екрану. - Дата звернення: 10.02.2018.

5. Маханець Л. Л. Моделювання ризику в зовнішньоекономічній діяльності : автореф. дис. ... канд. екон. наук : 08.03.02 / Маханець Л. Л. ; КНЕУ. - Київ, 2002. $20 \mathrm{c}$.

6. МСФ3 7 «Фінансові інструменти: розкриття інформації» [Електронний peсурс]. - Режим доступу: URL: http://zakon3.rada.gov.ua/laws/show/929_007. - Назва з екрану. - Дата звернення 20.02.2018.

7. Петросян Н. Э. Основные риски внешнеэкономической деятельности российских компаний / Н. Э. Петросян // Известия ПГПУ им. В. Г. Белинского. 2011. - № 24. - С. 374-377.

8. Прямі інвестиції (акціонерний капітал) [Електронний ресурс] / Державна служба статистики України. - Режим доступу: URL: https://ukrstat.org/uk/operativ/operativ2014/zd/pik/pik_u/pik_rik_2014.html. - Назва 3 екрану. - Дата звернення 22.02.2018.

9. Рум'янцев А. П. Зовнішньоекономічна діяльність : навч. посіб. / А. П. Рум’янцев, Н. С. Рум’янцева. - Київ : Центр навч. літ., 2004. - 377 с.

10. Свідерська А. Поняття та класифікація ризиків у зовнішньоекономічній діяльності підприємства / А. Свідерська // Галицький економічний вісник. Тернопіль : ТНТУ, 2014. - Т. 46, № 3. - С. 113-121.

11. Bańko M. (red.), Wielki słownik wyrazów obcych / red. M. Bańko. - Warszawa : PWN, Wydawnictwo Naukowe PWN, 2010.

12. Forex map: display exchange rates changes over time on a world interactive map [Electronic recource]. - Mode of access: URL: http://fxtop.com/en/forex-map.php. - Last access 23.02.2018. - Title from the screed.

13. Jajuga K. Zarządzanie ryzykiem / red. K. Jajuga. - Warszawa : PWN, 2007.

14. Kaczmarek T. T. Zarządzanie ryzykiem w handlu międzynarodowym / T. T. Kaczmarek. - Warszawa : Difin, 2012.

15. The Logistics Performance Index, World Bank [Electronic recource]. - Mode of access:

URL

http://databank.worldbank.org/data/reports.aspx?source=2\&series=LP.LPI.OVRL.XQ. - Last access 23.02.2018. - Title from the screed. 


\section{References:}

1. State Statistics Service of Ukraine. (2017). Foreign Trade Balance of Ukraine in 2017, February 14, 2018, no. 61/0/08.2vn-18, [online] Available at: URL: www.ukrstat.gov.ua. [Accessed 20 February 2018]. Title from the screen.

2. Logistics of the Efficiency Index 2016 - Germany again in the leaders. (2016). Jekonomicheskie izvestija [Economic news], [online] Available at : URL: http://eizvestia.com/uk/ekonomika-ukr/full/366-indeks-efektivnosti-logistiki-2016nimechchina-znovu-v-liderax. [Accessed 14 February 2018]. Title from the screen.

3. Levchenko, M.O. (2013). Formation of risk management mechanism in foreign economic activity of machine-building enterprises. D.Ed. Khmelnytskyi National University.

4. Mamchyn, M.M. (2011). Influence of logistic risks on increasing the efficiency of enterprises. [online] Available at: URL: http://ena.lp.edu.ua:8080/bitstream/ntb/13816/1/8_45-51_Vis_720_Menegment.pdf. [Accessed 10 February 2018]. Title from the screen.

5. Makhanets, L.L. (2002). Modeling of risk in foreign economic activity. D.Ed. Kyiv National Economic University.

6. International standard for financial statements 7. Financial Instruments: Information Disclosures. (2012). [online] Available at : URL: http://zakon3.rada.gov.ua/laws/show/929_007. [Accessed 20 February 2018]. Title from the screen.

7. Petrosjan, N.Je. (2011). The main risks of foreign economic activities of Russian companies. News of Penza V.G. Belinsky State Pedagogical University [Izvestija Penzenskogo gosudarstvennogo pedagogicheskogo universiteta imeni V. G. Belinskogo], no. 24, pp. 374-377.

8. State Statistics Service of Ukraine. Direct investments (share capital). [online] Available at : URL: https://ukrstat.org/uk/operativ/operativ2014/zd/pik/pik_u/pik_rik_2014.html. [Accessed 22 February 2018]. Title from the screen.

9. Rumiantsev, A.P. (2004). Foreign Economic Activity: a manual. Kyiv : Tsentr navchalnoi literatury.

10. Sviderska, A. (2014). Concept and classification of risks in the foreign economic activity of the enterprise. Halytskyi ekonomichnyi visnyk [Galician Economic Bulletin], Vol. 46, no. 3, pp. 113-121.

11. Bańko, M. Ed. (2010). Wielki stownik wyrazów obcych. Warszawa : PWN, Wydawnictwo Naukowe PWN.

12. Forex map: display exchange rates changes over time on a world interactive map. [online]. Available at : URL: http://fxtop.com/en/forex-map.php. [Accessed 23 February 2018]. Title from the screen.

13. Jajuga, K. Ed. (2007). Zarzadzanie ryzykiem. Warszawa : PWN, 2007. 
14. Kaczmarek, T.T. (2012). Zarzadzanie ryzykiem w handlu międzynarodowym. Warszawa : Difin.

15. World Bank. The Logistics Performance Index. [online] Available at : URL : http://databank.worldbank.org/data/reports.aspx?source=2\&series=LP.LPI.OVRL.XQ. [Accessed 23 February 2018]. Title from the screen.

() Ксендзук В. В., 2018 